\title{
GASTRONOMY AS A FORM OF CULTURAL TOURISM. A GREEK TYPOLOGY
}

\author{
Polyxeni Moira, Technological Education Institute of Piraeus \\ Dimitrios Mylonopoulos, Technological Education Institute of Piraeus \\ Aikaterini Kontoudaki, Directorate of International Relations/Ministry of Tourism of Greece
}

\begin{abstract}
Foods, as well as other factors, such as accommodation, attractions, recreational activities and transport are key parts of the tourism product of host destinations. It has been found that in recent years, tourism choices have not been determined only by the simple biological need to eat, but also by the desire to try interesting products within an appropriate environment. Modern, experienced travelers look for destinations' quality, as linked to a deeper knowledge of the culture and lifestyle of the inhabitants of the place they are visiting. As lifestyles of people are deeply related to what and how they eat, how they prepare food and in what environment, what the rituals of food consumption are, combined with the architecture and place, a strong demand has been created for local food and a trend of what is called "gastronomic/culinary tourism". A survey was carried out in order to explore the forms of product supply, commercialization strategy as well as methods to promote gastronomic tourism in Greece. In particular, the search was carried out through the internet businesses in Greece involved in the field of gastronomy and tourism, using keywords such as gastronomy, Greek cuisine, Greek breakfast, wine routes, olive routes, etc. Then, the findings were classified into categories in order to evaluate their activity. The survey revealed that companies involved in the field of gastronomy are numerous and of various nature. These include restaurants, hotels, guest and rural houses, tourism agencies, food manufacturers, food markets, museums, exhibition halls, etc. Their activities are equally varied and creative (related to wine, honey, herbs, etc, cultural routes that have to do with a product, thematic museums, etc). Due to the lack of targeted central tourism policy in the field, it is proposed to further explore the field and record domestic gastronomic resources at regional administrative levels in order to effectively valorize and promote them with a view to establishing each region as a distinct gastronomic destination.
\end{abstract}

Keywords: Gastronomy, Gastronomic-cultural tourism, Wine tourism, Cultural routes

\section{GASTRONOMIJA KAO OBLIK KULTURNOG TURIZMA. GRČKA TIPOLOGIJA}

Sažetak

Hrana, kao i ostali faktori, poput smeštaja, znamenitosti, rekreacionih aktivnosti i prevoza je ključni deo turističkog proizvoda receptivnih destinacija. U poslednjih nekoliko godina se pokazalo da na izbore u turizmu ne utiče samo prosta biološka potreba za jelom, već i želja da se probaju zanimljivi proizvodi u odgovarajućoj sredini. Moderni $\mathrm{i}$ iskusni putnici traže od destinacija kvalitet, što je uslovljeno dubljim znanjem o kulturi i načinu života žitelja mesta koje posećuju. Budući da su stilovi života tesno povezani sa ishranom, načinom pripreme hrane i ambijentom u 
kome se ona sprema, ritualima konzumiranja, kao i arhitekturom i mestom konzumacije, stvorena je velika potražnja za lokalnom hranom i trend nečeg što se zove "gastronomski/kulinarski turizam". Sproveden je upitnik kako bi se istražili oblici ponude proizvoda, strategija komercijalizacije, kao i metodi promovisanja gastronomskog turizma u Grčkoj. Potraga za grčkim firmama iz oblasti gastronomije i turizma je obavljena putem interneta, a korišćene su ključne reči poput "gastronomija", grčka kuhinja, grčki doručak, vinski putevi, putevi maslina, itd. Rezultati su potom klasifikovani po kategorijama, kako bi se ocenila njihova aktivnost. Upitnik je pokazao da su preduzeća koje se bave gastronomijom mnogobrojna i raznovrsna. To uključuju restorane, hotele, prenoćišta i konake, turističke agencije, proizvođače hrane, pijace, muzeje, izložbene prostore, itd. Njihove aktivnosti su raznolike i kreativne (kulturne rute proizvoda i tematski muzeji vezani za vino, med, trave, itd.). Usled nedostatka usmerene, centralizovane politike u oblasti turizma, predlaže se dalje istraživanje oblasti i beleženje domaćih gastronomskih resursa na regionalnim administrativnim nivoima, kako bi se oni efektivno valorizovali i promovisali, a sve u cilju ostvarivanja svakog regiona kao posebne gastronomske destinacije.

Ključne reči: gastronomija, gastronomsko-kulturni turizam, vinski turizam, kulturne rute

TIMS Acta (2015) 9, 135-148

\section{Culture and tourism}

Culture and tourism are so closely linked and mutually supporting activities that they are considered to be two sides of the same coin: Indeed, those who travel to any destination often seek to know its culture. Boniface (1995) argues that, without culture, all places would look the same and there would be no incentive to visit various destinations in order to feel a different sense of place. It is widely accepted thus that what essentially pushes humans to travel to different parts of the world is this quest for diversity, differentiation - or heterotopia in Foucault terms - and a desire to escape everyday routine.

In Greece, earliest recorded movements that date back to Antiquity refer to those tours designed to make travelers more familiar with other cultures (Thales, Anaximander, Herodotus, Plato, Strabo, Pausanias, etc.). Cultural tourism is considered to be the oldest form of tourism. Visiting historical sites, cultural landscapes, museums and fairs, as well as attending events have always been parts of the overall tourism experience (McKercher \& Du Cros, 2002, p. 1).

Cultural tourism began to be recognized as a special category of tourism in the late '70s, when researchers and tourism operators found that many people traveled with a view to understanding the culture and cultural heritage of the host destinations (Tighe, 1986, pp. 2-5).
Cultural tourism not only constitutes "the most effective means of promoting understanding and visibility for the cultural identity of a country or a region, while contributing to economic and social development of less developed regions", but also a form of sustainable tourism since "it does not invoke 'excessive pressure' on natural, social, human and built environment, causing 'alteration' of it, as it is the case with other common forms of mass tourism" (Moira, 2009, p. 23).

In 1985, the World Tourism Organization gave two definitions of cultural tourism. The first is "narrower" and refers to "the journey for essentially cultural motivations, such as study tours, travel to see theater, music or dance performances, festivals and other cultural events, visits to archeological sites, monuments, museums, educational trips and travel to study nature, folk culture or art and pilgrimages". The broader definition, in contrast, covers "all movements of persons made in order to satisfy the human need for diversity/variety, tending to raise the cultural level of the individual and giving rise to new knowledge, experience and encounters" (WTO, 1985, p. 6; Richards, 1996; Richards: 1996/2005).

Actually, it is difficult to find an appropriate definition for cultural tourism. This is due to the fact that cultural tourism has several aspects, both tangible and intangible, such as works of art, language, gastronomy, art and music, architecture, historical sites and monuments, festivals and cultural events, religion, education, clothing, 
etc. In this respect, today cultural tourism has become an "umbrella term", covering a wide range of related activities, such as historical tourism, tourism focusing on the fine arts, museums tourism, religious tourism, industrial tourism, gastronomic tourism, wine tourism, etc. (Moira, 2009, p.26).

In sum, cultural tourism could be defined as travel undertaken predominantly with the intention to participate in various activities and gain new experiences related to culture, such as participating in festivals and cultural events, getting acquainted with the history and tradition of regions, sites and countries, visiting areas with traditionally built environment, visiting cultural monuments and museums, becoming acquainted with local customs and local gastronomy (WTO, 1985; ICOMOS, 1999; Moira, 2009, pp. 25-26).

In this light, the cultural heritage of a place does not consist only of the cultural achievements of the past and present. The lifestyles of residents, as well as the food culture of everyday life (wine and bread, main alimentary products, artisanal production technology, traditional food and local cuisine) also identify the specific cultural identity of each place.

\section{Food as asocial need and cultural symbol}

Food and nutrition have been thoroughly investigated by both sociologists and anthropologists over the last twenty years (MacClancy, 1992; Beardsworth \& Keil, 1996; Fine, 1996; Lupton, 1996; Mennell, Murcott, \& Van Otterloo, 1992; Warde, 1996; Bell \& Valentine, 1997; Warde \& Martens, 2000). Characteristic of the social function of food is that it constitutes a core activity requiring a specific space for its consumption in almost all social events, such as weddings, funerals, birthdays, anniversaries, meetings of friends, business lunches, etc. (Tiger, 1992). The sea activities take various forms, such as tea parties, professional lunches or dinners, lunches or dinners with friends, Sunday lunches or dinners, weddings or alumni receptions, celebration of a success parties, etc. In all these cases, food constitutes an effective and powerful tool for bonding and developing social relations ${ }^{1}$.

In addition, food is a symbol of social status. What we eat is an indication of who we are, being, thus, a powerful social symbol (Kim, Eves, \& Scarles, 2009; Chang, Kivela, \& Mak, 2010). Furthermore, food is something that could be offered, being asign of generosity and a way to establish or strengthen alliances. The type and quality of food, the way of preparing, the pattern of its consumption, the decoration of the table and the table manners are all important features that distinguish people, religions and social classes. Food connects us with others, creates a sense of community, and strengthens the sense of "belonging" to a group ${ }^{2}$. Thus, in their quest for social recognition, people tend to adopt the alimentary habits of the social group they wish to join and despise what the group considers of lower class or religiously or nationally inadmissible. Moreover, anthropologists, such as Farb \& Armelagos (1980) and Douglas (1982) have pointed out, through their studies, the central role of food consumption in social rituals of various nature.

Food consumption is strongly influenced by factors such as the natural environment (Mennell, Murcott \& Van Otterloo, 1992) and culture of a place (Harrington \& Herzog, 2007, pp.4-5). By saying natural environment, we mean mainly the geographical location and the prevailing climatic conditions. The cultural environment refers to religion (Moira, 2009, pp. 76-78), history and ethnic diversity, local traditions and values. The environment affects not only the agricultural production, but also the harvest, processing, preservation and patterns of food consumption. It affects the food ingredients, the cooking methods and techniques of food and drinks preparation, the recipes as well as the dining etiquette.

\section{Gastronomy and tourism}

Due to the sepeculiarities and variations, food as well as other factors, such as accommodation, attractions, recreational activities at host destination sand transport are key parts of their tourism product (Reynolds, 1994). Moreover, tourism choices in recent years have not been determined only by the "trivial" need to eat, but also by the desire to try interesting products in an appropriate environment (Mennell, 1985; Finkelstein, 1989; Pillsbury, 1990; Fürst et al., 1991).

Over the last years, the role of food as related to the "image" of a tourism destination has become an 
increasingly popular field of interest for researchers, the scientific community, tourism professionals (Long, 2004) as well as the food industries and national governments. In this respect, studies have been conducted to examine the role the food is playing in the image of a destination, contributing for it to become a choice for potential visitors. According to data of the UNWTO, for about $44 \%$ of travelers around the globe, food is one of the three criteria to take into consideration when they decide where to travel (Foodservice, 2009, p. 36). In addition, according to UNWTO, even if gastronomy or wine is not the dominant motive for selecting a destination, a significant increase is recorded when evaluating the role of food as secondary or additional and supplementary incentive to determine tourist choices. According to the relevant surveys, eating in restaurants constitutes the 2nd most popular activity for visitors to the US and the 1st leisure activity of Americans when they visit other countries (UNWTO, 2012, pp. 6-7).

Gastronomy is considered an important cultural product, not only being by itself very attractive for visitors, but also constituting a valuable complement to the conventional portfolio of cultural products offered by destinations, which includes the monuments, museums, local architecture, etc. According to Kivella \& Crotts (2006, pp. 354-355), gastronomy is a composite and multifaceted activity, since it is very closely related to, and often inseparable from food, wine and other beverages, including elements of chemistry, literature, biology, geology, history, anthropology, music, philosophy, psychology and sociology.

A study conducted by Mintel (2009) demonstrates that in recent years a steadily increasing number of tourists has been recorded showing a special interest in food and beverages. According to Henderson (2004; 2009) and Quan \& Wang (2004), food is an important factor of attraction, which either enhances or constitutes the core element of the tourist experience. Further more, local gastronomy has been found to be an important criterion to inform the decision to choose a travel destination linked to alternative forms of tourism, such as agrotourism (Kastenholz et al., 1999; Lorenzini et al., 2010) and urban tourism (Gyimothy et al., 2000; Joppe et al., 2001). Other authors argue that gastronomy strongly influences the decision on summer vacation
(Decrop \& Snelders, 2005).

The terms used to denote the search for destinations that offer quality and good food are "food tourism", "gastronomy tourism", and "culinary tourism". The dominant term in recent years has rather been "culinary tourism".

The Greek word "gastronomy" (in Greek

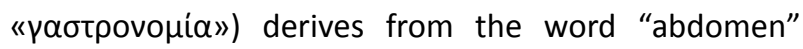

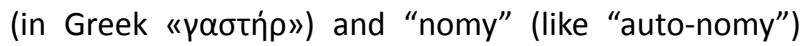
- "Nomos", which means knowledge or law. The term designates the art of haute cuisine, the set of rules for the selection of suitable primary materials and the preparation of dishes which satisfy both the taste and the visual pleasure. It also means, in general, any activity related to cooking and enjoying food (Bampiniotis, 2002, p.401). In contrast, the term "culinaria" refers to the local cuisine and the foods of a country or a place, namely the comestibles and the cooking techniques that are typical of the local cuisine (Kivela \& Crotts, 2006, p. 355).

The Greek word "gastronomy" was registered in the official dictionary of the French Academy in 1835. The French writer François Rabelais (1483-1553) was the one who first introduced the Greek term in his famous work "The Fourth Book of Pantagruel", referring to the god of food, Gaster. For ancient Greeks, meal time was an opportunity to provide food not only to body but also to spirit.

The Greek poet and philosopher Archestratusis considered the father of gastronomy (4th century BC). His most important work is "Hedypatheia" ("Life of Luxury"), which was completed in $350 \mathrm{BC}$ and is considered the first cookbook in the world (GNTO, 1998, p.5). An other important work is "Deipnosophistae" (Deipnosophists), work of Athenaeus ${ }^{3}$ (end of the 2 nd century AC early 3rd century AC), which is an important manual of gastronomy, referring to many different grapes varieties, fine food and its recipes, properties of the fruits of the earth - beneficial or not, birds, oil, vinegar, and of other products (Papanoutsos, 1974).

Roman Marcus Gavius Apicius follows, who is considered the author of one of the oldest books (3rd and 4th century BC) of gastronomy, namely "De re coquinaria" (Tromaras, 1991). Other famous historical figures of that period who were involved in gastronomy, are the emperor Caligula, known for his sophisticated 
Roman banquets and the Roman general Lucullus (Kyriazopoulou, 1998).

The history of gastronomy spans through the Middle Ages and the Italian Renaissance, until the time of the development of culinary art in France, which is considered the only organized gastronomy system in the world.

The first to use the term "culinary tourism" was Long (1998), who pointed out the contribution of food and wine to obtain knowledge of foreign cultures. Wolf (2002) followed, defining "culinary tourism" as the journey with the purpose of exploring and enjoying the experience of food preparation and drinking, largely acquiring unique culinary experiences. Later, Hjalanger, \& Richards (2002) referred to gastronomy tourism, Boniface (2003) used the term "tasting tourism", while Hall used "food tourism" (Hall et al., 2003). This variation on the use of terms usually also includes drinks consumption, alcoholic or not (Hall, 2003). However, the so-called "wine tourism" is studied and promoted as a separate and distinct activity (Hall et al.,2000). In recent years, it has also been common to use the Greek term for this activity, namely "oeno tourism" (Laidet \& Tóth, 2007; Canja, 2010; Bibicioiu \& Cretu, 2013, p. 31).

Researchers argue that senses and memories from participation in food and wine preparations during holidays are very special, since they translate into very personal experiences (Filkelstein, 1989; Mennel, Murcott, \& Van Otterloo, 1992). Additionally, this kind of experiences may often even alter personal eating and wine consumption habits (Johns \& Clarke, 2001; Johns \& Kivela, 2001).

Further more, several attempts have been made to define gastronomic tourism. In particular, Hall and Sharples (2003) define gastronomic tourism as a travel experience to a region with a distinct gastronomy, with recreational purposes that include visits to primary or secondary food producers, gastronomic events, rural markets and cooking demonstrations in order to taste quality local products and generally every kind of activity that is associated with food. In this case, gastronomy is the main motive of choosing a tourism destination or at least one of the most important ones.

Smith and Xiao (2008, p. 289) define gastronomic tourism as every travel experience through which one learns, appreciates and enjoys well-known products of local gastronomy. According to the authors, the term "gastronomic tourism" refers both to those trips whose the primary motivation is gastronomy and those through which tourists seek to experience different and exceptional dining moments, although this does not constitute the primary purpose of their trip. Other authors argue that "gastronomic tourism" refers to travelers seeking to explore new foods and flavors, using food as a means to get to know different cultures and ways of life (Long, 2004).

According to the International Culinary Tourism Association (2009), gastronomic tourism is "the pursuit of unique and memorable food and beverage experience... Eating local food and drinking local wine give diners the sense that they are truly in a different culture...The natural beauty of a place, the authenticity of the surroundings and the presentation of the food, are key features of gastronomic tourism ${ }^{4 \prime \prime}$.

As already said, many authors consider gastronomy to be closely linked to cultural tourism, viewing food as a manifestation of the culture of a destination (Van Westering, 1999; Hjalager \& Corigliano, 2000).

According to the World Food Travel Association, culinary or food tourism refers to the search for specific or unique food and beverage experiences ${ }^{5}$. Apart from eating good food, gastronomy represents a complete and wide network of activities linked to food and nutrition. It includes the supply of food, food preparation and presentation, food consumption patterns as well as the social context of food and the symbolism of its consumption. Based on this approach to the concept of culinary tourism, the term may cover, a part from restaurants and wineries; cookbooks, shops selling items related to cooking, shops selling food, cooking shows on television, food advertising, visits to industries producing food, festivals dedicated to a product, etc.

All of the above is widely used by the tourism industry to develop related tourism products, such as educational cooking programmes combined with culinary tours, farm stays where guests stay in the house of the farmer, which gives them the opportunity to help him/her in the agricultural works, participate in food cooking and, of course, taste it (agritourism or agricultural tourism), experiencing this way the "rural 
culture" through the routes of local flavors (Allen \& Albala, 2007, p. 112).

In sum, it could be argued that the role of tourism and gastronomy is "symbiotic", meaning that destinations offer food, recipes, cooking techniques, chefs and cultural basis, which converts gastronomy into the ideal product for tourist consumption (Fields, 2002; Richards, 2002; Scarpato, 2002).

\section{Classification of the resources of gastronomic tourism}

A survey was carried out through search engines (from 01/01/2013 till 31/12/2013) in order to explore the forms of product supply, commercialization strategy, as well as methods to promote culinary tourism in Greece. In particular, the internet businesses in Greece were covered involving the field of gastronomy and tourism, using keywords such as gastronomy, Greek cuisine, Greek breakfast, wine routes, olive routes, etc. Then, the findings were classified into categories in order to evaluate their activity. It is also worth noting that the

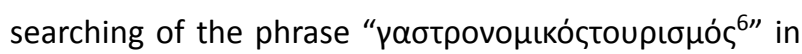
the internet (as accessed in Google on 10/01/2013) gave

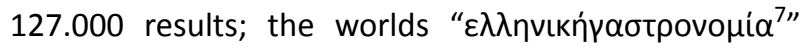

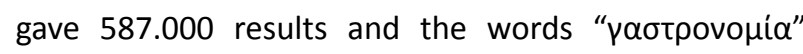
661.000 results.

The study revealed that companies involved in the field of gastronomy are numerous and of various nature. These include restaurants, hotels, guest and rural houses, tourism agencies, food manufacturers, food markets, museums, exhibition halls, etc. Their activities are equally varied and creative (having to do with wine, honey, herbs, etc., cultural routes themed around a product, thematic museums, etc). According to the above, offer based on gastronomic resources can be classified as follows:

\section{1) National or local cuisine at restaurants}

Offering local delicacies to tourists is the basis of creating an attractive gastronomic vacation package. In Greece, the typical traditional restaurants are called taverns, where visitors can consume representative Greek dishes, accompanied with Greek wine, ouzo or beer. The taverns are divided into fish-taverns, if located on islands or coastal areas and specialize in serving sea food or barbecue houses, where meat is served mainly grilled or spitted (a traditional Greek habit). Unfortunately, few of these restaurants offer authentic traditional national or local cuisine. The problem is more acute in tourist areas. According to SETE (2009, p. 31), Crete, Thessaloniki, and Santorini are the only exceptions, since there one can find comparatively more quality restaurants offering local dishes. In addition, the major draw back is that even where one can find restaurants of this kind, they work in isolation, meaning not as a part of a comprehensive strategic plan or concrete policy on gastronomy tourism.

2) National or local cuisine at hotel restaurants

The cuisine of a hotel, since it targets an international clientele, must respond to two types of demand, namely these tourists who wish to try the national or local cuisine and those who prefer to consume food that is familiar to them, i.e. international cuisine or the cuisine of their country. In this light, the hotel has three choices: a) to lay emphasis on the international cuisine, b) to specialize in local flavors and dishes, showcasing the local products, or c) to provide a choice, offering both international and national cuisine, which is a possibility mainly for large hotels, due to the obvious cost that it entails.

In Greece, upon the initiative of the Hellenic Chamber of Hotels $(\mathrm{HCH})$, the programme "Greek Breakfast" is implemented ${ }^{8}$. The "Greek Breakfast" programme valorizes the cultural - gastronomic riches of Greece and links them with the Greek hotel industry (GTP, 2014).

The basis of Greek breakfast, as promoted by the Greek hotels are the main products of the Mediterranean diet, such as bread, screw nuts, olive oil, olives, yogurt, honey, cheese, charcuterie, fresh vegetables, legumes, pies, pastries and fresh fruits. On, each region of Greece, depending on its climatic conditions, soil composition, produced products and cultural relations and exchanges has formed a specific culinary culture and local cuisine. Thus, each region has its own culinary wealth, e.g. different characteristics are specific to the Cretan cuisine, the cuisines of Macedonia, Epirus, Peloponnese, the Aegean islands, etc. At the same time, the objective of the programme is to familiarize producers with consumers, and get tourists in contact with the production of products, in order to promote the place, 
the local landscape and the natural environment which produces specific flavors, i.e. culinary experiences to be combined with the experiences of landscapes, local techniques and the way of life of rural people.

\section{3) International brands of gourmet restaurants}

Over the last 15 years, famous Chefs, such as the French Alain Ducasse, the British Gordon Ramsay, and the Japanese Nobu Matsuhisa, who are often also known through popular television cooking shows, have opened restaurants in various parts of the world. These restaurants, holding brand names such as Nobu, Spoonand Maze, were initially opened in cities with significant demand for haute gastronomy, from both the local population and their visitors. Branches of these chain restaurants have been opened in popular tourism destinations, such as Mauritius, Sardinia, the Bahamas and Hawaii. The existence of a gourmet brand in a country or a tourism destination is considered to ensure visibility, while introducing the region into the international culinary map (SETE, 2009, p. 17).

In Greece, such kinds of chain restaurants have already been introduced, e.g. the operates in the Astir Palace hotel complex.

\section{4) National and local cuisine in the airline companies}

Offering national or local delicacies and beverages (wine or beer) to travellers/airlines customers is a major asset with a view of creating an attractive vacation package to a gastronomic destination. It has been argued that the quality and variety of meals offered by the airlines and cruise lines leads to increased customer base and hence increased revenues. In this case, food is complementary to the tourist activity (Hjalager \& Antonioli-Corigliano, 2000, p. 281).

In this respect, the air lines offer customers/travelers meals, snacks, drinks and desserts, often emphasizing their origin. For example, Aegean Airlines, under the programme "Discover the Greek Cuisine" ${ }^{5}$, enables passengers to enjoy a meal inspired by traditional recipes from the Greek islands.

5) National and local cuisine in the cruise lines

Offering national or local delicacies and beverages to cruise lines customers is also the basis of creating an attractive cruise package. Greek cruise companies promote the Greek gastronomic identity, highlighting its quality and diversity, combined with its simplicity and its beneficial properties. For example, Louis Cruises, which is a Cypriot company, offers its travelers seminars, held by specialized gastronomes and interactive cooking demonstrations from cooks and with flavors specially selected from the local destinations - depending on the port of arrival ${ }^{10}$.

6) Places to visit related to the cultivation and production of foods and beverages

This activity refers to the opportunity to visit places where food and drink is produced (e.g. wineries, breweries, olive presses, farms, dairies, etc.). During the visit, the tourist can attend and learn about the production process, handle a tool, test the product, and eventually purchase it directly from the place where it is produced.

In Greece, because of the rich wine tradition of the country, there are many vine yards and wineries that tourists can visit. Indicative examples are the organic vineyard and winery of "Domain Porto Carras" in Halkidiki, ${ }^{11}$ the "Gaia" vineyard and winery in Nemea ${ }^{12}$, the winery Achaia Clausin Patras, the Boutari Santorini winery, ${ }^{13}$ etc. which attract many visitors, domestic and foreign tourists.

\section{7) Cultural routes and tours}

Due to the special interest of visitors to get acquainted with the local gastronomy and the wine culture of host destinations, many cultural/gastronomic/ wine routes and tours are offered. The routes vary in theme, cost and period to travel. Initiators are usually local, regional and national tourism organizations, as well as professional associations (i.e. associations of wine producers). One of the most known and popular in Greece is the "Wine Roads of Northern Greece".

The "Wine Roads of Northern Greece" is a tour suggested for wine tasting in Northern Greece. The project started when 13 wine producers of northern Greece decided to establish the Wine Producers Association of the Macedonian Vineyard in 1993. The Association's aim was to support the vine-growing and wine-making tradition and give the opportunity to Greek and foreign visitors to discover the hospitality of the 
vineyards of Northern Greece. In 2002, wineries in Epirus and Thrace joined the association, which was renamed to the "Wine Producers' Association of the Northern Greece Vineyard" with the trade name "Wine Roads of Northern Greece". Nowadays, the 37 members of the association propose to visit 41 wineries on 8 routes that traverse all Northern Greece from one end to the other, making stops at major vineyards of Thessaly (Rapsani and Krania), Epirus, Macedonia and Thrace. The suggestion is complemented with quality restaurants, taverns, guest houses and hotels, shops with traditional products, as well as places that specialize in alternative activities. All these services are offered by associated members of the "Wine Roads of Northern Greece", who have been assessed according to common standards and have the corresponding specific label ${ }^{14}$.

A similar initiative is "Nemea Wines" in Corinth" ${ }^{15}$. This suggestion is the result of a study funded by the European Union and implemented by the Local Union of Municipalities and Communities of Corinth in cooperation with other stakeholders of the public and the private sector. The route includes, apart from visiting vine yards and wineries, a tour to archaeological sites, accommodation in selected hotels and eating local delicacies in local restaurants.

Another interesting programme is financed under Axis 4 - LEADER approach to Rural Development Programme (RDP) 2007-2014, with the title of "Gastronomy Routes and the Culture of Flavors". It refers to a cooperation network of 18 areas from 4 different countries (Greece, Italy Cyprus and Portugal) entitled "MedEat". The network aims to create gastronomic routes and related tourism packages, joint promotion and marketing of local gastronomy, local product sand, generally speaking, the culture of local flavors. The national lead partner and coordinator of this transnational cooperation programme is the Development Agency of Heraklion S.A. ${ }^{16}$. The involved actors seek to promote the gastronomic routes that they have created in the regions participating in the programme. For this reason, they have created travel guides and maps with information on these tours ${ }^{17}$.

\section{8) Programmes of specialist Tour Operators}

Tourists interested in culinary tours can either organize by themselves their own journey, using the information provided by local tourism organizations or participate in a package tour, organized by a specialist tour operator.

Related programmes include a wide range of activities, such as gastronomy seminars, involving popular authors, food journalists and food bloggers, visits to food markets and work places of small scale producers, visits to organic farms, sightseeing and guided tours, cooking demonstrations by famous chefs, meals at wineries or at award-winning restaurants, etc.

\section{9) Food Storytelling}

Storytelling on food means the association of cooking recipes and products with specific narratives of mythology, history, folklore, geography, cultural heritage and people of an area, locality or region. The art of storytelling has been revived in recent years, since this cultural revival gives visitors the opportunity to explore and get acquainted with various stories and figures of the past (Gersie, 1992). Of particular interest is storytelling concerning issues linking the environment with man, through myths, stories and beliefs of the past. Storytelling allows for a better understanding of the interaction between man and its environment. Food storytelling contributes to a better understanding of the distinctiveness, the significance and the need that led to the consumption of specific foods, depending on the location, religion, people and geography and, generally, all those factors that make people consume food in a certain way and a certain space.

Narrations on the food history are a useful tool for the tourism sector and an attractive factor for visitors. In this light, many historical sites, monuments, etc. use storytelling about a dish as a dominant or complementary element in their tourism promotion. The example of Chantilly castle in France can be mentioned here: in its website, the famous whipped cream is promoted, telling its story in relation with the castle and the region ${ }^{18}$, inviting guests to taste the famous authentic cream and take a tour of the castle and its gardens.

In Greece, although there is an interest in associating known foods and recipes with the Greek mythology ${ }^{19}$, history, legends and traditions, there is not a coordinated policy in this direction, which would 
also allow the creation and establishment of a distinct culinary identity for different areas.

10) Events of gastronomic interest

These are events dedicated to gastronomy, addressing both residents of a region and tourists. Said events vary in form and subject: They may be gastronomy festivals in selected restaurants or hotels of a city or region celebrations after the harvest of an agricultural product, celebrations dedicated to specific products (e.g. a wine festival, aubergine celebration, sardines celebration, potato celebration, etc.), cooking demonstrations and contests, trade shows, etc.

Of particular interest is the event of Mount Athos Area - Kouzina, which takes place in different areas of $A_{\text {thos }}{ }^{20}$. The event is organised by the Tourism Development Agency of the area of Athos. The festivities last for one month and include contests and lessons of traditional cooking, tasting that promote organic products and their production techniques, flavours of Greek refugees of the past, flavours of ancient Greeks, traditional flavours, monastic flavours, Mediterranean flavours, etc.

\section{1) Shops selling foods and beverages}

In recent years many shops selling traditional local gastronomy products have been operating at every destination. These shops sell foods and beverages that are typical of the destination. Similar shops operate in all major airports, giving the tourists the opportunity to buy and take with them typical products of their vacation place. Said items usually have special decoration and packaging.

\section{2) Thematic museums (dedicated to a product)}

In Greece, small thematic museums operate independently - they are not usually promoted or supported by the national or regional tourism organizations - often as a part of vine yards or wineries. Indicative examples are the Wine Museum in Mesoghaia Attica ${ }^{21}$, the Wine Museum of K. Lazaridis in Kapandriti, Attica Region ${ }^{22}$, the European Museum of Bread in Varnava ${ }^{23}$ and the Museum of Bread in Amfiklia ${ }^{24}$.

There are also museums that area part of a network of thematic museums, created and operated by the Cultural Foundation of Piraeus Bank ${ }^{25}$, dedicated to traditional products, such as the Museum of Olive and Greek Olive Oil in Sparta or the Museum of Industrial Oil Production in Lesbos island.

13) Conferences, lectures, workshops and trade fairs on gastronomy

This category includes conferences on gastronomy, what ever the organizer. These conferences take place either in stand alone convention centers or conference centers that belong to a hotel. National and international gastronomy fairs have a similar content, promoting national or regional/local dishes. Said events could be supplemented by food tasting, tasting of local wines and other beverages, cultural events, cooking classes or demonstrations, cookbook sales and sales of books on healthy eating, often accompanied by a conference or workshop on gastronomy.

\section{4) Cooking lessons and seminars}

Over the last years, there has been a high demand for learning the culinary art of host destinations. The tourism market immediately responded to this need by offering courses and seminars on cooking and food tasting. Seminars of this kind are usually organized by hotels, restaurants, specialized tour operators or local authorities and stakeholders, lasting from a few hours to a few days.

In Greece some travel agencies offer cooking lessons as part of package tours, such as the travel agency Cook Med that offers "flavor trips" to many different Greek locations. The trips form a complete tourism package (travel, accommodation, food in traditional taverns), also including tours to cultural sites, visit to a production place (dairy), acquaintance with the natural environment of the visited area as well as a cooking class given by an experienced chef, based on the local cuisine ${ }^{26}$. In a similar vein, Balos Travel in Crete offers traditional Cretan cooking lessons, combined with a tour to local gardens in order to collect the vegetables and herbs that will be used to prepare the meal during the lesson, accompanied with local wine, homemade bread and traditional desserts ${ }^{27}$.

Apart from organized tourism packages, cooking lessons are also offered by individual hotels, such as Hotel Asteras Paradise in the island of Paros ${ }^{28}$. 
15) Spa Specialized treatments

This new trend has been recorded in recent years, linking gastronomy to wellness tourism, by using foods and drinks as cosmetic substances for spa treatments (SETE, 2009, p. 21).

In Greece, special services are offered, e.g. the Premium Spa in Santorini island that offers treatments with olive oil or honey ${ }^{29}$, the Lotus Spa that offers treatments with mastic of Chios island, honey or olive $\mathrm{oil}^{30}$, the Cavo Olympo Luxury Resort \& Spa in Olympus mountain that offers treatments with olive oil ${ }^{31}$, etc.

In places with thermal baths, as Platystomo, spa treatments with natural ingredients, such as honey, chamomile and milk, combined with thermal water are promoted $^{32}$

\section{Conclusion}

The composite and creative nature of tourism activity emerges in the best way through the activity known as "Gastronomic Tourism". Around food and beverages a huge industry has been developed, involving a wide range of tourism businesses, such as restaurants, hotels, tourism agencies, airlines, shops and outlets, as well as of tourism activities, such as cultural routes and tours, cooking lessons, food and wine tasting, participation in agricultural activities, specialized conferences and seminars, thematic museums, etc.

The survey revealed that companies involved in the field of gastronomy are numerous and of various nature. These include restaurants, hotels, guest and rural houses, tourism agencies, food manufacturers, food markets, museums, exhibition halls, etc. Their activities are equally varied and creative (treatment with wine, honey, herbs, etc; cultural routes on a product, thematic museums, etc).

Popular culinary destinations offer a mixture of products, services and activities especially designed for tourists in order to promote their typical products and cuisine, their manufacturers' creativity, the uniqueness of their tradition, addressing the visitor with a comprehensive and memorable travel and culinary experience.

The Greek cuisine has significant advantages, such as being part of the healthy and famous Mediterranean diet, a great variety of ingredients and flavors combined with a unique cultural and natural environment to enjoy them. However, the Greek gastronomy faces also certain weaknesses, such as quality problems, lack of effective promotion of its rich resources, and lack of a central related tourism policy. Minor exceptions are the islands of Crete and Santorini as well as the city of Thessaloniki.

Within this framework, it is proposed to further explore the field, recording the domestic gastronomic resources at regional administrative level, and promote them through an organized and well-targeted tourism strategy with a view to establishing each region as a distinct gastronomic destination.

\section{FOOTNOTES}

1 What are the Physiological and Social Functions of Food? Preserve articles, in http://www.preservearticles.com/2012010419789/ what-are-the-physiological-and-social-functions-of-food.html, accessed on $10 / 1 / 2014$

2 A typical example are the alimentary habits and diet prescribed by religions or various denominations, which are characteristic of a religious group, eg. Jews, Muslims, etc. (Moira - Mylonopoulos \& Kondoudaki, 2012; Moira \& Mylonopoulos, 2013)

3 "Deipnosophists", deriving from the words "deipnos" that means "dinner" and "sophists" that means "professors", is the title of a 15 -volumes book of the ancient Greek Athenaeus of Naucratis in Egypt. Protagonists of the book are ancient Greeks grammarians, lexicographers, orators, sophists, philosophers, musicians and others. In "Deipnosophists", Athenaeus narrates in his friend Timocrates what was said at a symposium hosted by the very rich and learned man, Roman Larinsios. In that work, a Roman hosts a dinner with 29 guests, and during their discussions, life, manners and customs, as well as art and scientific knowledge of the ancient Greeks are described. Said work also constitutes a manual of gastronomy, referring to texts concerning food and wine.

4 Gastronomic Tourism - International - May 2009, in http://oxygen. mintel.com/display/417677/\#, accessed on 12/1/2014.

World Food Travel Association, in http://www.worldfoodtravel. org/, accessed on 20/2/2014

6 "Gastronomy tourism" in Greek

7 "Greek Gastronomy" in Greek

The action has been implemented by 252 hotels, mainly in Crete, Macedonia, Thrace and Corfu. It is estimated that, over the next three years, the participating hotel units will increase to 1000 (GTP, 2014). 
9 Aegean Airlines, Discover the Greek Cuisine, in http:// el.aegeanair.com/hrisimes-plirofories/en-ptisei/anakalupste-tinelliniki-kouzina.

10 Louis Cruises (2014)., You in the Epicenter of the Culinary Delight of the Greek Traditional Cuisine, in http://louiscruises.com/gr/ cruise-themes/10/our-greek-cuisine-themed-cruises-put-you-inthe-middle-of-the-aegean-kitchen.html, accessedon12/3/2014.

11 Guided tours and wine tasting include a winery tour, wine tasting accompanied with cheese or whole lunch, and seminars. In addition, visitors can stay at the hotel of the company (Domain Porto Carras, 2014).

12 Gaia's winery (2014), in http://www.gaia-wines.gr/el/gaia/gaia, accessed on $03 / 4 / 2014$

13 Boutari Santorini winery, in http://www.boutari-santorini.gr/, accessed on $03 / 4 / 2014$

14 Wine Roads of Northern Greece, in http://www.wineroads.gr/, accessed on $03 / 4 / 2014$

15 Nemea Wines (2014). "Wine Routes", in http://www.nemeawines. gr/drhomoi_toy_krasiohu_1.html, accessed on 03/4/2014.

16 From the island of Crete, the Development Agency of Heraklion S.A., the Development Agency of Lasithi and the Crete Development Organization participate in the programme. From Northern Greece, participating agencies are the Imathia Development Agency S.A., the Development Agency of Western Macedonia S.A., the Development Agency of Kilkis S.A. and the Development Agency of Florina S.A. From the Ionian islands, the Development Agency of Ionian islands S.A. in Corfu and the Development Cooperative Agency of Local Administration of Zakynthos S.A. also participate in said programme.

17 "Gastronomic Routes in Crete", Cretalive.gr, in http://www. cretalive.gr/crete/view/gastronomikes-diadromes-me-shmeioanaforas-thn-krhth/147617

18 Domaine de Chantilly, The Story of Chantilly's whipped cream, in http://www.domainedechantilly.com/en/domaine-de-chantilly/ chantillys-whipped-cream/story-chantillys-whipped-cream, accessed on $12 / 2 / 2014$

19 A typical example is the Greek souvlaki (meats kewer, kebab) that is one of the main dishes of the Greek cuisine. The recipe has its roots in Antiquity. The first reference is made in the Homeric Epics, where Achilles cooked on embers pieces of meat. In "Deipnosophists", Igissipos in his cooking book entitled "Opsartitiko", refers to a dish called "Kandaflos", containing pieces of meat grilled, cheese, pita bread and dill, which was served with broth (Athenaeus, Deipnosophists, 12, 516d). Roman writings of the 1st century AC refer to offal skewer, while, quite later, in Constantinople, many street vendors were selling souvlaki with pita. In the 1940 s, the snack begins to spread in refugee neighborhoods, such as Korydallos, and in Piraeus, a Constantinopolitan refugee made in 1950 the first wrapped souvlaki kebab (AKS Hotels, in http://www.akshotels.com/ soyvlaki-istoria.html, accessed on 12/1/2014).
20 In the shadow of Holy Mount Athos, in the golf of Mount Athos, in the Ammouliani island, at the foot of the mountain of Aristotle, in Strimonikos bay, in Acanthios bay, on the outskirts of Cholomontas (Tourism Development Agency of the area of Athos, 2014).

21 Wine Museum, in http://www.mouseioinou.gr/moyseio, accessed on $01 / 4 / 2014$.

22 Wine Museum, in http://www.domaine-lazaridi.gr/gr/museum, accessed on $01 / 4 / 2014$.

23 European Museum of Bread in Varnava, in http://www. visitmarathon.gr/index.php/el/mouseio-artou-varnava/, accessed on $01 / 4 / 2014$.

24 Bread Museum, in http://www.breadmuseum.gr/, accessed on $01 / 4 / 2014$

25 The Piraeus Bank Group Cultural Foundation (P.B.G.C.F.) is a voluntary non-profit foundation with residence in Athens. Within the context of its Corporate Social Responsibility programmes, it implements actions related to culture. In recent years, in coopeartion with the local authorities has created a network of industrial museums throughtout Greece, supporting the preservation and showcasing Greece's cultural heritage, with an emphasis on its artisanal and industrial technology. In the network of the museums of said Foundation, many educational programmes, exhibitions, lectures, seminars and other events take place. The Museum of Industrial Oil Production in Lesvos island, the Museum of Olive and Greek Olive Oil in Sparta and the Silk Museum in Soufli are some of the above-mentioned museums (Moira \& Parthenis, 2011, p.65).

26 Cook Med, Aitoloakarnanía, in http://www.cookmed.gr/ taksidia-geysis/cooking-travel-in-greece/30--project, accessed on $03 / 4 / 2014$.

27 Balos Travel, in http://balos-travel.com/cretan-traditionalcooking-lessons-kissamos-chania-crete.aspx?lang=el, accessed on $03 / 4 / 2014$

28

Asteras Paradise, in http://www.asterasparadise.gr/el, accessed on $03 / 4 / 2014$

29 Santorini Premium Spa, in http://www.santonet.gr/healthbeautystyle/premiumspa/massagetherapies.htm, accessed on03/4/2014.

30 Lotus Spa, in http://www.santorinispa.gr/, accessed on03/4/2014

31 Cavo Olympo Luxury Resort \& Spa, in http://www.cavoolympo.gr/ index.php\#, accessed on03/4/2014

32 Thermae Platystomo, in http://www.platystomo.gr/?id=18, accessedon03/4/2014

\section{REFERENCES}

Allen, G., \& Albala, K. (2007). The Business of Food: Encyclopedia of the Food and Drink Industries. USA: Greenwood Press 
Bampiniotis, G. (2002). Dictionary of the Modern Greek Language. 2nd Edit. Athens: Center of Lexicology, EPE

Beardsworth, A., \& Keil, T. (1996). Sociology on the Menu: An Invitation to the Study of Food and Society. London: Routledge.

Bell, D., \& Valentine, G. (1997). Consuming Geographies: We Are Where We Eat. London: Routledge.

Bibicioiu, S., \& Cretu, R.C. (2013). Enotourism: A Niche Tendency within the Tourism Market. Scientific Papers Series Management. Economic Engineering in Agriculture and Rural Development, 13(2), 31-40.

Boniface, P. (2003). Tasting Tourism: Travelling for Food and Drink. Aldershot: Ashgate

Boniface, Pr. (1995). Managing Quality Cultural Tourism. London and New York: Routledge.

Canja, C. M. (2010). Role of Education in Oenotourism Development. Journal of EcoAgriTourism, 6(1), 162-166.

Chang, R. C. Y., Kivela, J., \& Mak, A. H. N., (2010). Food preferences of Chinese tourists. Annals of Tourism Research, 37(4), 989-1011.

Decrop, A., \& Snelders, D. (2005). A Grounded Typology of Vacation Decision-making. Tourism Management, 26, 121-132.

Douglas, M. (1982). Food as a System of Communication. In The Active Voice, (pp. 82-129). London: Routledge and Kegan Paul.

Farb, P., \& Armelagos, G. (1980). Consuming Passions, the Anthropology of Eating. Boston: Houghton Mifflin.

Fields, K. (2002). Demand for the Gastronomy Tourism Product: Motivational Factors. In Hjalager, A. M., \& Richards, G. (eds.) (2002) Tourism and Gastronomy (pp. 36-50). Fischler, C.

Fine, G. (1996). Kitchens: The Culture of Restaurant Work. Berkeley: University of California Press.

Finkelstein, J. (1989). Dining Out. A Sociology of Modern Manners. Cambridge: Polity Press:

Foodservices (2009). In http://www.foodservices.gr/

Fox, R. (n.d.). Food and Eating: An Anthropological Perspective, The Myth of Nutrition, In http://www.sirc.org/publik/food_and_ eating_1.html

Fürst, E.L., Prättälä, R., Ekström, M., Holm, L., \& Kjaemes, U. (1991) (eds.) Palatable worlds: Sociocultural Food Studies (pp. 111-130). Oslo: Solum Forlag

Gersie, A. (1992) Earthtales: Storytelling in Times of Change. London: Green Print, pp. 1. In http://www.unesco.org/education/tlsf/ mods/theme_d/mod21.html, accessed on 20/3/2014.

GTP (Greek Travel Pages), (2014). Greece Aims To Strengthen Promotion Of Food Products To Boost Tourism. In http://news. gtp.gr/2014/06/11/greece-aims-strengthen-promotion-foodproducts-boost-tourism/;http://news.gtp.gr/2014/07/08/ hoteliers-greece-urged-serve-greek-peaches-guests/, accessed on $9 / 3 / 2014$

Gyimothy, S., Rassing, C., \& Wanhill, S. (2000). Marketing Works: A Study of Restaurants on Bornholm. Denmark. International Journal of Contemporary Hospitality Management, 12, 371-379.

Hall, C.M., Sharples, L., Cambourne, B., \& Macionis, N. (2000). Wine Tourism around the World: Development, Management and Markets. London: Butterworth-Heinemann

Hall, C.M., \& Sharples, L. (2003). The Consumption of Experiences or the Experience of Consumption? An Introduction to the Tourism of Taste. In Food Tourism Around the World (pp.1-24). Oxford: Elsevier Butterworth-Heinemann

Hall, C. M. (2003). Wine, Food and Tourism Marketing. New York: The Haworth Hospitality Press

Harrington, R., \& Herzog, C. (2007). Chef John Folse: A Case Study of Vision, Leadership \& Sustainability. Journal of Hospitality and Tourism Education, 19(3), 5-10.

Henderson, J. (2004). Food as a Tourism Resource: A View from Singapore. Tourism Recreation Research, 29(3), 69-74.

Henderson, J. C. (2009). Food Tourism Reviewed. British Food Journal, 111(4), 317-326.

Hjalager, A. M., \& Corigliano, M. A. (2000). Food for Tourists Determinants of an Image. International Journal of Tourism Research, 2, 281-293.

Hjalanger, A. M., \& Richards, G. (2002). Tourism and Gastronomy. London: Routledge

ICOMOS (1999). Cultural Tourism Charter, Paris, ICOMOS. In http://www. international.icomos.org/charters/tourism_greek.pdf, accessed on $13 / 3 / 2014$

International Culinary Tourism Association. (2009). Introduction to culinary tourism. In http://www.culinarytourism.org/?page=intro, accessed on 10.03.2014

ITH/13/8.COM/Decisions, Convention for the Safeguarding of the Intangible Cultural Heritage. Intergovernmental Committee for the Safeguarding of the Intangible Cultural Heritage, Eighth session, Baku, Azerbaijan, 2-7 December 2013, Paris, 7 December 2013.

Johns, N., \& Clarke, V. (2001).Mythology Analysis of Boating Tourism. Annals of Tourism Research, 28(2), 334-359.

Johns, N., \& Kivela, J. (2001). Perceptions of the first time Restaurant Customer, Food Service Technology, 1(1), 5-11.

Joppe, M., Martin, D.W., \& Waalen, J. (2001). Toronto's Image as a Destination: A Comparative Importance Satisfaction Analysis by Origin of Visitor. Journal of Travel Research, 39, 252-260.

Kastenholz, E., Davis, D., \& Paul, G. (1999). Segmenting Tourism in Rural Areas: The Case of North and Central Portugal. Journal of Travel Research 37, 353-363. 
Kim, Y. G., Eves, A., \& Scarles, C. (2009). Building a model of local food consumption on trips and holidays: A grounded theory approach. International Journal of Hospitality Management, 28(3), 423-431

Kivela, J., \& Crotts, C. (2006). Tourism and Gastronomy: Gastronomy's Influence on How Tourists Experience a Destination. Journal of Hospitality and Tourism Research, (30), 354-377.

Kyriazopoulou, B. (trans.) (1998). Short History of Gastronomy and Cooking. edit. Ermias

Laidet, M., \& Tóth, K. (2007). VITOUR - The European World Heritage Vineyards. Management Team of the VITOUR Programme.

Long, L.M. (Ed.). (2004). Culinary Tourism. Lexington: University Press of Kentucky

Lorenzini, E., Calzati, V., \& Paolo, G. (2011). Territorial Brands for Tourism Development. A Statistical Analysis on the Marche Region. Annals of Tourism Research, 38(2), 540-560.

Lupton, D. (1996). Food, the Body and the Self. London: Sage Publications

MacClancy, J. (1992). Consuming Cultures. London: Chapman

McKercher, B., \& du Cros, H. (2002). Cultural Tourism: The Partnership Between Tourism and Cultural Heritage Management. Binghamton, NY: The Haworth Hospitality Press.

Mennel, S., Murcott, A., \& Van Otterloo, A.H. (1992). The Sociology of Food: Eating, Diet and Culture. London: Sage

Mennell, S., Murcott, A., \& Van Otterloo, A. (1992). The Sociology of Food: Eating, Diet and Culture. Current Sociology, 40(2), 1-152.

Mennell, S. (1985). All Manners of Food. Eating and Taste in England and France from the Middle Ages to the Present. Oxford: Basil Blackwell

Mintel (2009). Mintel reviews global consumers trends of 2009. In http://www.mintel.com/press-centre/mintel-corporate/ mintel-reviews-global-consumer-trends-of-2009, accessed on 13.03.2014.

Moira P., \& Mylonopoulos, D. (2013). Is Religion a Determinant Factor Influencing Food Consumption during Vacation? The Reaction of Tourism Industry. Proceedings of the 2013 Annual Conference of The International Society of Travel and Tourism Educators (ISTTE) Conference. Geotourism. A New Approach to Travel and Tourism Education. (Vol. XXV, pp. 120-133). October 17-19, 2013. Detroit, Michigan, St Clair Shores, MI: International Society of Travel and Tourism Educators.

Moira P., Mylonopoulos, D., \& Kondoudaki, A. (2012). The Management of Tourist's Alimentary Needs by the Tourism Industry. The Parameter of Religion. International Journal of Culture and Tourism Research, 5(1), 129-140.

Moira, P., \& Parthenis, S. (2011). Cultural - Industrial Tourism. Open Library.
Moira, P. (2009). Religious Tourism. Athens: Interbooks

Papanoutsos, E. (edit.) (1974). Atheneus, Deipnoshophists. (trans.) Fotiadis, E. Library of Ancient Authors. Edit. Zacharopoulos I.

Pillsbury, R. (1990). From Boarding House to Bistro. Cambridge, MA: Unwin Hyman

Quan, S., \& Wang, N. (2004). Towards a Structural Model of the Tourist Experience: An Illustration from Food Experiences in Tourism. Tourism Management, 25(3), 297-305.

Reynolds, P. (1994). Culinary Heritage in the face of Tourism. Progress in Tourism, Recreation and Hospitality Management, (6), 189-194.

Richards, G. (1996). Production and Consumption of European Cultural Tourism. Annals of Tourism Research, 23(2), 261-281.

Richards, G. (1996/2005). Cultural Tourism in Europe, ATLAS. In http:// www.atlas-euro.org/pages/pdf/cultural\%20tourism\%20in\%20 europe.PDF, accessed on13/3/2014.

Richards, G. (2002). Gastronomy: An essential Ingredient in Tourism Production and Consumption? In A. M. Hjalager \& G. Richards (eds.) Tourism and Gastronomy (pp. 3-20). London: Routledge

Scarpato, R. (2002). Gastronomy as a Tourist Product: The Perspective of Gastronomy Studies. In A.M. Hjalager \& G. Richards (eds.) Tourism and Gastronomy (pp. 51-70). London: Routledge

SETE, (2009). Gastronomy in Greek tourism marketing. Athens: SETE

Smith. S. L. J., \& Xiao, H. (2008). Culinary Tourism Supply Chains: A Preliminary Examination. Journal of Travel Research, Vol. 46, 28-299.

Tiger, L. (1993). The Pursuit of Pleasure, Food and Pleasure, In http://www.sirc.org/articles/tigerpleasure.html, accessed on $10 / 3 / 2014$

Tighe, A. (1986). The Arts/Tourism Partnership. Journal of Travel Research, 24(3), 2-5.

Tromaras, L. (1991). Apikius, The Cooking of Romans. Edit. University Studio Press.

UNWTO (2012). Global Report on Food Tourism, AM Reports, Vol. 4, UNWTO, Spain.

Van Westering, J. (1999). Heritage and Gastronomy: The Pursuits of the 'New Tourist'. International Journal of Heritage Studies, 5, 75-81.

Warde, A., \& Martens, L. (2000). Eating out: Social Differentiation, Consumption and Pleasure. Cambridge: Cambridge University Press

Warde, A. (1996). Consumption, Food and Taste: Culinary Antinomies and Commodity Culture. London: Sage

Wolf, E. (2002). Culinary Tourism: A Tasty Economic Proposition. Portland: International Culinary Tourism Taskforce

World Travel Organization (1985). The States' Role in Protecting and Promoting Culture as a Factor in Tourism Development and the 
Moira, P., Mylonopoulos, D., Kontoudaki, A. - Greek gastronomy as a form of cultural tourism 2015. Fakultet za sport i turizam, Novi Sad, TIMS Acta 9, 135-148

Proper Use and Exploitation of the National Cultural Heritage of Sites and Monuments for Tourists. Madrid: World Tourism Organization.

Datum prijave rada: 21.04.2015.

Datum prihvatanja rada: 24.04.2015.

\section{Kontakt}

Polyxeni Moira, Piraeus University of Applied Sciences, Technological Education Institute of Piraeus,

P. Ralli and Thivon 250, Athens, Greece

E-mail:xeniamoira@yahoo.gr

Dimitrios Mylonopoulos, Piraeus University of Applied Sciences, Technological Education Institute of Piraeus,

P. Ralli and Thivon 250, Athens, Greece

E-mail:dimilon2002@yahoo.gr

Aikaterini Kontoudaki, Directorate of International Relations/Ministry of Tourism of Greece, Athens

E-mail:kontoudaki_c@mintour.gr 